\title{
HASIL ANALISIS PENGEMBANGAN MULTIMEDIA INTERAKTIF KINEMATIKA DAN DINAMIKA PARTIKEL UNTUK PEMBELAJARAN FISIKA SISWA R-SMA-BI KELAS X SEMESTER 1
}

\author{
Asrizal, Amra Ahmad \\ Jurusan Fisika FMIPA Universitas Negeri Padang
}

Asrizal_unp@yahoo.com

\begin{abstract}
ABSTRAK
Rintisan Sekolah Bertaraf Internasional (RSBI) menuntut sistem pembelajaran Fisika berbahasa Inggris dan berbasis ICT. Namun sumber belajar berbahasa Inggris dan berbasis ICT masih belum banyak tersedia. Salah satu alternatif untuk mengatasi masalah adalah mengembangkan multimedia interaktif untuk pembelajaran Fisika berbahasa Inggris menggunakan software CMS Joomla. Pengembangan dilakukan dengan mendapatkan teks, suara, animasi dan video berbahasa Inggris yang berasal dari negara-negara yang menggunakan bahasa Inggris sebagai bahasa utama. Penggunaan multimedia interaktif diperkirakan dapat membuat pembelajaran Fisika menjadi lebih menarik dan membantu siswa dalam memahami Fisika berbahasa Inggris. Tujuan umum dari penelitian ini adalah untuk menghasilkan multimedia interaktif untuk pembelajaran Fisika, khususnya Kinematika dan Dinamika Partikel yang memiliki deskripsi baik, valid, praktis, dan efektif.

Penelitian yang dilakukan termasuk jenis Research and Development (R\&D). Desain penelitian yang digunakan adalah desain eksperimen before-after yang diterapkan pada objek penelitian. Sebagai objek penelitian ada dua yaitu multimedia interaktif dan siswa kelas X.2 R-SMA-BI di SMAN 3 Padang yang berjumlah 25 orang. Instrumen pengumpul data yang digunakan dalam penelitian ini adalah: lembar validasi tenaga ahli, lembar uji kepraktisan menurut guru sebagai praktisi, lembar uji kepraktisan di dalam pembelajaran dan tes hasil belajar. Teknik analisis produk dan data yang digunakan adalah teknik mendeskripsikan, metode grafik, analisis deskriptif, dan analisis perbandingan berkorelasi.

Berdasarkan analisis data yang telah dilakukan dapat dikemukakan hasil penelitian. Pertama, multimedia interaktif memiliki validitas tinggi dengan rata-rata dari tenaga ahli 88,14 . Kedua, desain multimedia interaktif kinematika dan dinamika partikel untuk kelas $\mathrm{X}$ semester 1 memiliki menu utama home, introduction, competence, material, task, download, quiz, dan closure yang dilengkapi dengan video dan animasi serta dikemas dalam format $D V D$. Ketiga, penggunaan multimedia interaktif dalam implementasi pembelajaran menurut KTSP adalah praktis dengan rata-rata nilai kepraktisan adalah 82,05 dan hasil penilaian guru Fisika 87,28. Penggunaan multimedia interaktif dalam implementasi pembelajaran menurut KTSP adalah efektif yang ditandai dengan peningkatan hasil belajar Fisika siswa secara berarti.
\end{abstract}

Kata kunci: RSBI, Multimedia Interaktif, KTSP, Hasil Belajar

\section{PENDAHULUAN}

Manusia pada saat ini telah berada pada era globalisasi. Dalam era globalisasi tidak terdapat hambatan geografis dan batas negara untuk melakukan interaksi. Disamping itu, era globalisasi dapat membantu memudahkan manusia untuk mengembangkan kemampuan dan ambisinya. Hal ini melahirkan persaingan yang sangat ketat dalam bidang ilmu pengetahuan, teknologi, dan sumber daya manusia (SDM).

Tuntutan era globalisasi terhadap perkembangan ilmu pengetahuan dan SDM yang ada di dalamnya telah meningkat dibandingkan dengan era kehidupan sebelumnya. SDM yang 
dibutuhkan harus mampu berkompetisi secara global yaitu SDM yang mempunyai keterampilan tinggi, pemikiran yang kritis, sistematis, logis, kreatif, dan kemauan bekerja sama yang efektif. SDM yang tidak mampu memenuhi tuntutan tersebut akan mendapatkan kesulitan untuk menghadapi persaingan yang semakin ketat di era globalisasi.

Untuk memenuhi tuntutan era globalisasi dalam dunia pendidikan, pemerintah Indonesia mengeluarkan UU No. 20 tahun 2003 tentang Sistem Pendidikan Nasional. Dalam pasal 50 ayat 3 dinyatakan bahwa "Pemerintah dan/atau Pemerintah daerah menyelenggarakan sekurang-kurangnya satu satuan pendidikan pada semua jenjang pendidikan untuk dikembangkan menjadi satuan pendidikan yang bertaraf internasional." Di dalam Rencana Strategis (Renstra) Depdiknas 2005-2009 juga disebutkan bahwa "Untuk meningkatkan daya saing bangsa, perlu dikembangkan sekolah bertaraf internasional pada tingkat kabupaten/ kota melalui kerjasama yang konsisten antara pemerintah dengan pemerintah kabupaten/ kota yang bersangkutan, untuk mengembangkan SD, SMP, SMA, dan SMK yang bertaraf internasional”.

Dengan landasan hukum ini, pemerintah beserta satuan pendidikan berusaha membangun dan mengembangkan Sekolah Bertaraf Internasional (SBI). SBI adalah sekolah nasional yang telah memenuhi seluruh Standar Nasional Pendidikan (SNP) Indonesia serta mengembangkan keunggulan yang mengacu pada peningkatan daya saing yang setara dengan mutu sekolah salah satu negara Organization for Economic Co-operation and Development ( OECD ) atau negara maju lainnya yang mempunyai keunggulan (Puskur, 2008). Disamping itu, SBI menerapkan pembelajaran berbasis Information, Comunication, and Technology (ICT) dan berbahasa Inggris.

Pembelajaran pada SBI menggunakan bahasa Inggris sebagai bahasa pengantar. Bahasa Inggris digunakan dalam bidang studi Matematika dan IPA seperti Fisika, Biologi dan Kimia. Dalam pelaksanaan pembelajaran, guru SBI tidak hanya dituntut untuk melaksanakan pembelajaran menggunakan bahasa Inggris tetapi juga menerapkan pembelajaran berbasis ICT. Bahasa Inggris dan ICT terintegrasi dalam setiap model, metoda dan sumber belajar yang digunakan oleh guru dan siswa. Hal ini bertujuan agar siswa lulusan SBI memiliki keunggulan dalam bidang penguasaan bahasa Inggris dan ICT.

Untuk mengimplementasikan SBI, salah satu upaya yang telah dilakukan adalah dengan mengadakan Rintisan Sekolah Berstandar Internasional (RSBI) di satuan pendidikan. RSBI untuk satuan pendidikan SMA dikenal dengan R-SMA-BI. R-SMA-BI merupakan SMA Nasional yang telah memenuhi seluruh standar nasional pendidikan, menerapkan sistem kredit semester, dan dalam proses menuju SMA bertaraf internasional (Sungkowo, 2009: 10).

Pembelajaran pada kelas RSBI mengacu kepada pelaksanaan pembelajaran SBI. Pelaksanaan pembelajaran berbahasa Inggris dan sumber belajar berbasis ICT merupakan hal yang perlu untuk diimplementasikan RSBI. Kemampuan RSBI untuk mengimplementasikan hal tersebut dengan baik dan konsisten, akan memperkuat keberadaanya dalam proses menjadi SBI.

Namun fakta yang didapat di R-SMA-BI kelas X, XI dan XII SMAN 3 Padang adalah masih kurangnya sumber belajar berbahasa Inggris dan berbasis ICT yang dimiliki oleh guru. Padahal, tuntutan pembelajaran dari RSBI dan SBI adalah menggunakan sumber belajar berbahasa Inggris dan berbasis ICT. Dengan dasar ini dibutuhkan sumber belajar yang sesuai dengan tuntutan pembelajaran dalam RSBI dan SBI. Melalui cara ini guru bisa mengkomunikasikan materi ajar menggunakan bahasa Inggris untuk Fisika dengan baik kepada siswa, sehingga siswa dapat menerima informasi pembelajaran dan melatih kemampuan siswa menguasai bahasa Inggris dan ICT. 
Salah satu alternatif untuk mengatasi permasalahan ini adalah menghasilkan suatu sumber belajar berkualitas yang dapat digunakan sebagai media pembelajaran bagi siswa untuk mengkontruksi pengetahuan Fisika menggunakan bahasa Inggris. Sesuai dengan kemajuan ilmu pengetahuan dan teknologi, multimedia interaktif diperkirakan merupakan suatu alternatif yang dapat digunakan sebagai media pembelajaran Fisika yang sesuai dengan tuntutan pelaksanaan pembelajaran Fisika di RSBI.

Secara harfiah, multimedia merupakan perpaduan antara berbagai media yang berupa teks, gambar, grafik, suara, animasi, video yang yang dikendalikan secara digital (Tim Mata Kuliah Universitas Binus, 2007: 2-3). Vaughan (2004) di dalam Dadang (2009: 14) menjelaskan bahwa multimedia adalah sembarang kombinasi yang terdiri atas teks, seni grafik, bunyi, animasi dan video yang diterima oleh pengguna melalui komputer. Pernyataan ini sejalan dengan Heinich (2005) dalam Dadang (2009: 14) yang menyebutkan bahwa multimedia merupakan penggabungan atau pengintegrasian dua atau lebih format media yang berpadu seperti teks, grafik, animasi, dan video untuk membentuk aturan informasi ke dalam komputer.

Multimedia dapat digolongkan menjadi dua kategori, yaitu: multimedia linier dan multimedia interaktif. Multimedia linier adalah suatu media yang tidak dilengkapi dengan alat pengontrol apapun yang dapat dioperasikan oleh pengguna, multimedia ini berjalan berurutan, contohnya: TV dan film. Multimedia interaktif adalah suatu media yang dilengkapi dengan alat pengontrol yang dapat dioperasikan oleh pengguna, sehingga pengguna dapat memilih apa yang dikehendaki untuk proses selanjutnya (Didik, 2008). Chanier dalam Chang, 2002: 2 menyatakan bahwa multimedia interaktif adalah pendekatan instruksional yang mengintegrasikan instruksi dengan bantuan komputer dan multimedia. Contoh multimedia interaktif adalah multimedia pembelajaran interaktif, game, dan lain-lain (Didik, 2008).

Secara umum manfaat multimedia yang dapat diperoleh adalah proses pembelajaran lebih menarik, lebih interaktif, jumlah waktu mengajar dapat dikurangi, kualitas belajar siswa dapat ditingkatkan dan proses pembelajaran dapat dilakukan di mana dan kapan saja, serta sikap belajar siswa dapat ditingkatkan (Ivandri, 2011). Interaktivitas nyata disini adalah interaktivitas yang melibatkan fisik dan mental dari pengguna saat mencoba program multimedia (Gatot $\mathrm{P}$, 2008). Keunggulan lain dari teknologi multimedia adalah menarik perhatian, karena aplikasi ini memiliki teknik penyajian yang menarik; media alternatif dalam penyampaian pesan, karena diperkuat dengan teks, suara, gambar, video, dan animasi; dan meningkatkan kualitas penyampaian informasi (Eko N, 2009).

Materi yang berhubungan dengan sains adalah materi yang sangat cocok untuk dijelaskan melalui multimedia. Hal ini berkaitan dengan sifat dari materi sains sendiri yang banyak berhubungan dengan penjelasan suatu fenomena, proses, dan hal-hal lain yang dinamis (Gatot $P$, 2008). Penggunaan multimedia dalam pembelajaran akan dapat meningkatkan penguasaan siswa. Alasannya adalah orang mampu mengingat $20 \%$ dari yang dilihat, mampu mengingat $30 \%$ dari yang didengar, mampu mengingat 50\% dari yang didengar dan dilihat, serta mampu mengingat $60 \%$ dari yang didengar, dilihat dan dilakukan.Penggunaan multimedia interaktif dengan menampilkan fitur-fitur akan dapat dijadikan sarana komunikasi visual (Sri R, 2011).

Mengingat pentingnya multimedia interaktif untuk pembelajaran siswa R-SMA-BI maka peneliti tertarik untuk melakukan penelitian. Sebagai judul penelitian yaitu "Pengembangan Multimedia Interaktif Kinematika dan Dinamika Partikel untuk Pembelajaran Siswa R-SMABI Kelas X Semester 1". Ada tiga tujuan dari penelitian ini yaitu: menentukan validitas desain multimedia interaktif, untuk mendeskripsikan desain multimedia interaktif, dan untuk 
Prosiding Seminar Nasional Fisika

Universitas Andalas (SNFUA)

Padang, 15 Oktober 2011

ISBN 978-979-25-1953-2

menentukan kepraktisan dan keefektifan penggunaan multimedia interaktif dalam pembelajaran.

\section{METODOLOGI}

Jenis penelitian yang akan dilakukan adalah Research and Development (R\&D). Sugiyono (2006) mengemukakan pengertian $R \& D$ adalah metode penelitian yang digunakan untuk menghasilkan produk tertentu, dan menguji keefektifan produk tersebut. Disisi lain menurut Nana, S.S (2006) R\&D adalah suatu proses atau langkah-langkah untuk mengembangkan suatu produk baru atau menyempurnakan produk yang telah ada, yang dapat dipertanggung jawabkan. Produk tersebut tidak selalu berbentuk perangkat keras (hardware) seperti buku, alat bantu pembelajaran di kelas maupun di laboratorium, tetapi juga bisa berupa perangkat lunak (software) seperti program komputer untuk pengolahan data, pembelajaran di kelas, laboratorium, model pendidikan dan pembelajaran, dan evaluasi. Berarti produk merupakan bagian yang penting pada pada penelitian ini. Dalam R\&D eksperimen dapat dilakukan dengan cara membandingkan keadaan sebelum dan keadaan sesudah (before-after). Model eksperimen ini diperlihatkan seperti pada Gambar 1.

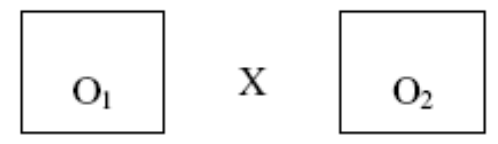

Gambar 1. Desain Eksperimen Sebelum-Sesudah

Disini $\mathrm{O}_{1}$ adalah nilai sebelum perlakuan, sedangkan $\mathrm{O}_{2}$ adalah nilai sesudah perlakuan. Eksperimen dilakukan dengan membandingkan hasil observasi $\mathrm{O}_{1}$ dan $\mathrm{O}_{2}$. Efektivitas pemberian perlakuan dapat diukur dengan cara membandingkan nilai $\mathrm{O}_{2}$ dengan $\mathrm{O}_{1}$. Bila nilai $\mathrm{O}_{2}$ lebih besar dari pada $\mathrm{O}_{1}$, maka dapat dikatakan perlakuan tersebut efektif.

Istrumen pengumpul data penelitian ada tiga macam yaitu instrumen uji validasi oleh tenaga ahli, instrumen uji kepraktisan yang terdiri dari dua bagian yaitu lembar uji kepraktisan oleh guru sebagai praktisi dan lembar uji keterlaksanaan di kelas, instrumen uji efektifitas. Instrumen uji validasi digunakan untuk menilai kevalidan dari desain multimedia interaktif menurut pemikiran rasional. Instrumen uji kepraktisan digunakan untuk menentukan keterlaksanaan penggunaan multimedia interaktif multimedia interaktif dalam pembelajaran menurut KTSP dalam kelas dan menurut guru sebagai praktisi. Lembaran tes hasil belajar digunakan untuk menentukan uji efektivitas penggunaan multimedia interaktif dalam pembelajaran menurut KTSP.

Dari data uji coba terbatas dilakukan dua analisis terhadap penggunaan multimedia interaktif dalam pembelajaran yaitu analisis kepraktisan dan analisis keefektifan. Analisis kepraktisan dilakukan untuk mengetahui apakah produk multimedia interaktif yang dibuat memenuhi kriteria kepraktisan ditentukan berdasarkan keterlaksanaan multimedia interaktif dalam proses pembelajaran. Analisis keefektifan dilakukan untuk mengetahui apakah multimedia interaktif yang dibuat memenuhi komponen kriteria keefektifan yakni tes hasil belajar.

Untuk menganalisis kepraktisan dan keefektifan penggunaan multimedia interaktif ini digunakan teknik analisis data yang sesuai. Ada empat macam teknik analisis data yang digunakan yaitu analisis statistik deskriptif, metoda grafik, analisis regresi linear dan korelasi, dan analisis perbandingan rata-rata. Analisis deksriptif digunakan untuk mengetahui informasi lebih rinci dari satu kelompok data hasil belajar siswa. Metoda grafik digunakan untuk memberikan kesan visual tentang kepraktisan penggunaan multimedia interaktif dalam 
pembelajaran. Analisis regresi dan korelasi masing-masing digunakan untuk menentukan hubungan hasil belajar sesudah dengan sebelum perlakuan dan menentukan nilai koefisien regresi. Analisis perbandingan rata-rata digunakan untuk menentukan keefektifan penggunaan multimedia interaktif dalam pembelajaran menurut KTSP.

\section{HASIL DAN DISKUSI}

Sesuai dengan tujuan penelitian yang telah ditetapkan, secara umum ada tiga hasil utama dari penelitian ini. Ketiga hasil tersebut meliputi: hasil uji valditas desain multimedia interaktif, deskripsi multimedia interaktif, hasil uji kepraktisan dan hasil uji keefektifan penggunaan multimedia interaktif.

\section{Hasil Validitas Desain Multimedia Interaktif}

Hasil validitas desain multimedia interaktif diperoleh dari 5 orang tenaga ahli. Tenaga ahli yang dimaksud adalah orang yang dipercaya mampu melakukan validasi multimedia interaktif. Tenaga ahli yang dipilih terdiri dari 5 orang dosen fisika yang berpengalaman dibidang Fisika Dasar dan Media Pembelajaran.

Lembaran penilaian dari dosen terdiri dari lima indikator yaitu kelayakan isi, penggunaan bahasa, penyajian pada multimedia interaktif, kegrafisan pada multimedia interaktif, dan kelengkapan multimedia interaktif. Nilai rata-rata penilaian dosen físika dapat diperjhatikan pada Gambar 2.

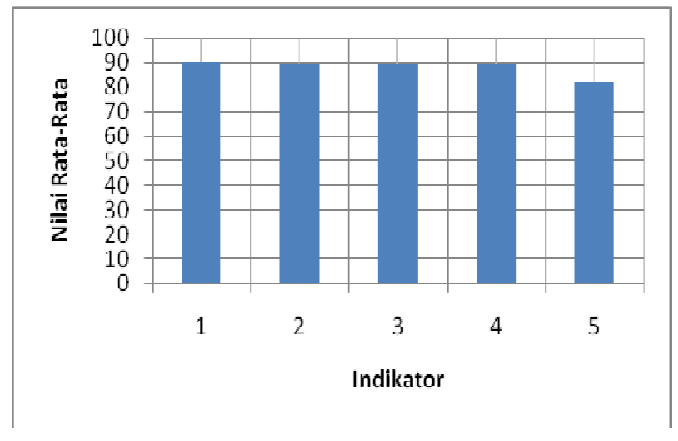

Gambar 2. Nilai Validitas Rata-Rata Tenaga Ahli

Dari Gambar 8, dapat dijelaskan nilai rata-rata setiap indikator multimedia interaktif . Nilai setiap indikator multimedia interaktif bervariasi antara 82,00 sampai 90,00 dengan rata-rata 88,14 . Berdasarkan nilai tersebut dapat dikemukakan bahwa semua indikator multimedia interaktif berada pada kategori baik sekali. Dengan demikian multimedia interaktif telah memiliki nilai baik sekali dengan tingkat validitas yang tinggi.

\section{Deskripsi Multimedia Interaktif}

Multimedia interaktif dibuat sesuai dengan desain yang telah disusun. Desain multimedia interaktif meliputi: menu utama, sub menu, template, layout, interaktivitas, video, animasi, jenis dan ukuran huruf, dan sebagainya. Multimedia interaktif dibuat menggunakan CMS dengan software Joomla! versi 1.0. Tampilan pada halaman utama multimedia interaktif diperlihatkan pada Gambar 3a.

Halaman utama memberikan gambaran umum pada user (pengguna) tentang multimedia pembelajaran interaktif. Pada halaman utama pengguna dapat mengetahui menu utama pada 
multimedia pembelajaran interaktif. Menu utama multimedia pembelajaran meliputi: home, introduction, competence, material, task, download, quiz, dan closure.

Secara umum konten dari multimedia interaktif terdiri dari empat bagian yaitu: materi pembelajaran, tugas, kuis interaktif, dan bahan yang dapat di-download. Pengguna dapat mengakses bagian-bagian multimedia pembelajaran melalui navigasi pada menu utama. Bagian pertama yang bisa diakses oleh pengguna adalah menu introduction. Introduction adalah menu yang menampilkan pengenalan multimedia pembelajaran secara singkat. Tampilan pada menu home dan menu introduction diperlihatkan oleh Gambar 3a dan 3b:
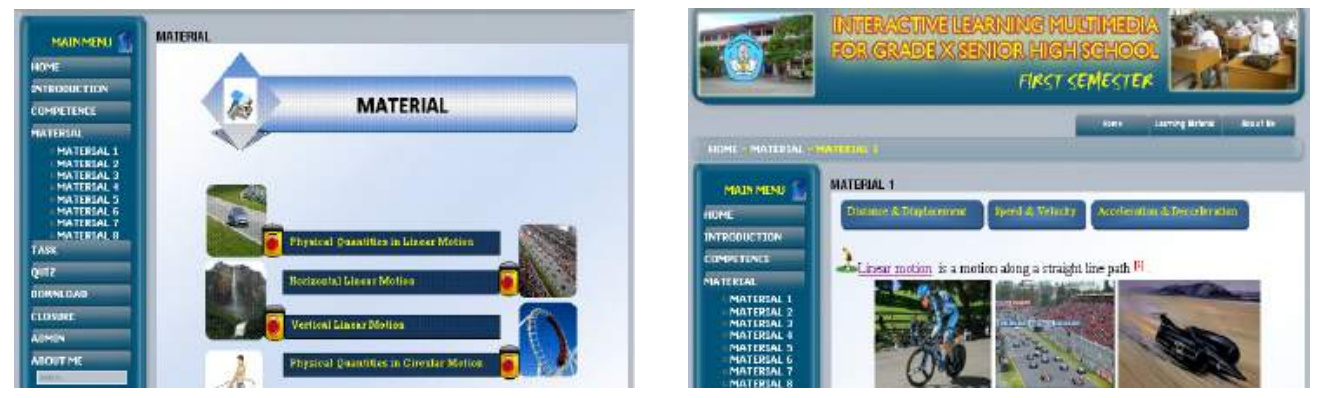

Gambar 3a. Tampilan Menu Material (kiri), Tampilan Salah Satu Sub Menu Material (kanan)

Pada halaman menu material ditampilkan judul materi untuk setiap pertemuan. Materi yang ditampilkan khusus untuk materi Kinematika dan Dianamika Partikel. Materi yang ditampilkan yaitu: physical quantities in linear motion, horizontal linear motion, vertical linear motion, physical quantities in circular motion, uniform circular motion and application, force and kinds of force, Newton's laws of motion, dan application of Newton's laws.

Pada menu utama material terdapat sub menu materi pembelajaran untuk setiap pertemuan. Jika sub menu tersebut diklik oleh pengguna, maka akan muncul halaman materi pembelajaran seperti Gambar 3b:
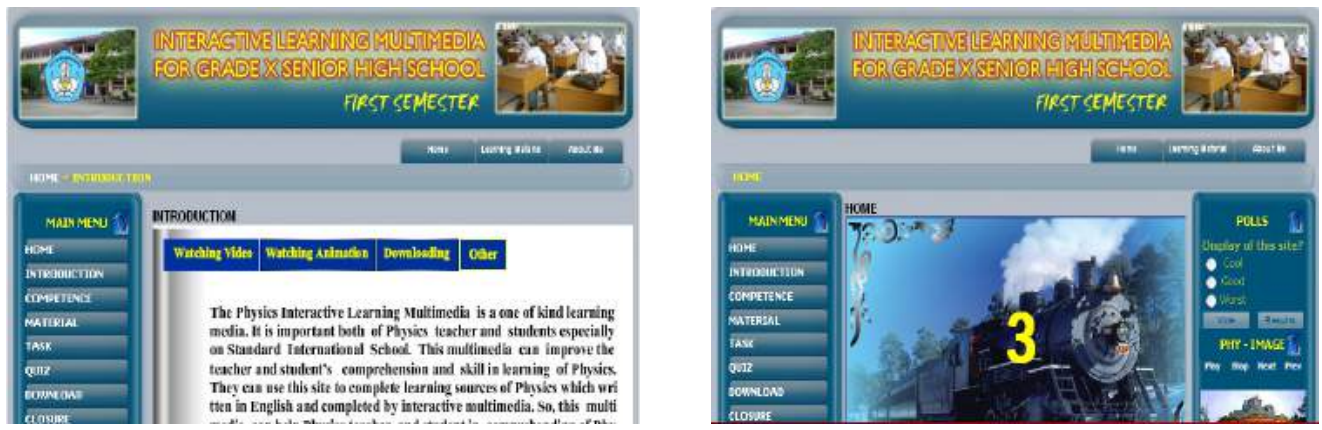

Gambar 3b Tampilan Menu Home (kiri), Tampilan Menu Introduction (kanan)

\section{Hasil Uji Kepraktisan}

\section{Hasil Uji Kepraktisan Menurut Guru Fisika}

Hasil uji kepraktisan menurut guru dianalisis berdasarkan instrumen lembaran uji kepraktisan menurut guru terhadap multimedia interaktif. Berdasarkan lembaran uji kepraktisan menurut guru tersebut dianalisis empat indikator. Keempat indikator tersebut adalah isi multimedia interaktif, sajian dalam multimedia interaktif, manfaat multimedia interaktif bagi guru, dan 
peluang implementasi multimedia interaktif . Nilai rata-rata penilaian guru dapat di lihat pada Gambar 4.

Berdasarkan data yang terdapat dalam grafik di atas dapat dijelaskan bahwa setiap indikator bervariasi antara 85,83 sampai 88,83 . Dari data tersebut dapat dinyatakan bahwa semua indikator sudah berada pada kategori sangat baik. Nilai terendah terdapat pada indikator peluang multimedia interaktif sebesar 85,83 , sedangkan nilai tertinggi terdapat pada indikator manfaat multimedia interaktif bagi guru sebesar 88,83 .

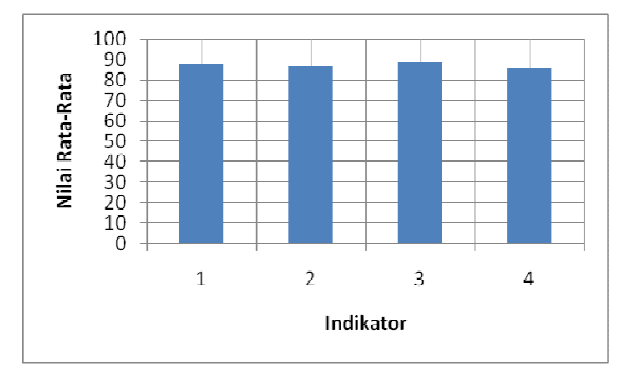

Gambar 4. Nilai Penilaian Rata-Rata Guru Fisika

Nilai hasil uji kepraktisan menurut guru terhadap multimedia interaktif dapat ditentukan dengan mencari nilai rata-rata semua indikator. Nilai rata-rata didapatkan sebesar 87,28. Dari nilai tersebut dapat dikemukakan bahwa semua indikator multimedia interaktif berada pada kategori sangat baik

\section{Hasil Uji Kepraktisan Dalam Pembelajaran}

Untuk menentuk kepraktisan implementasi multimedia interaktif dalam pembelajaran menurut KTSP dilakukan pengamatan terhadap keterlaksanaan aspek pada langkah-langkah pembelajaran. Keterlaksanaan implementasi multimedia interaktif diamati selama proses pembelajaran meliputi kegiatan pendahuluan, kegiatan inti, dan kegiatan penutup. Instrumen yang digunakan dalam pengambilan data ini adalah lembaran observasi. Lembaran observasi diisi oleh observer berdasarkan aktivitas yang dilaksanakan oleh guru dalam pembelajaran menggunakan multimedia interaktif. Uji kepraktisan penggunaan multimedia interaktif dilakukan untuk tiga kali pertemuan sehingga rata-rata nilai setiap aspek keterlaksanaan didapatkan dengan cara menjumlahkan nilai setiap aspek keterlaksanan dan membagi dengan jumlah pertemuan. Presentase keterlaksanaan penggunaan buku ajar físika pada kegiatan pendahuluan, kegiatan inti, dan kegiatan penutup dapat diperhatikan pada Gambar 5a, 5b dan $5 \mathrm{c}$.

Berdasarkan Gambar 5a dapat dijelaskan nilai keterlaksanaan aspek yang diamati selama kegiatan pendahuluan. Nilai keterlaksanaan guru mempersiapkan siswa secara fisik dan psikis untuk menghadapi pembelajaran adalah 83,33; nilai keterlaksanaan guru mereview materi pelajaran lalu yang berhubungan dengan materi pelajaran yang akan dibahas dengan tanya jawab adalah 75,00; nilai keterlaksanaan guru memotivasi siswa dengan mengajukan pertanyaan-pertanyaan yang berhubungan dengan materi yang akan dipelajari dalam pembelajaran adalah 91,67; nilai keterlaksanaan guru menyampaikan kompetensi dasar dan tujuan pembelajaran adalah 91,67.

Berdasarkan Gambar 5b dapat dijelaskan nilai keterlaksanaan aspek yang diamati selama kegiatan inti. Nilai keterlaksanaan guru meminta siswa untuk mengamati dan memikirkan peristiwa Fisika melalui video dan animasi yang terdapat dalam multimedia interaktif disertai ceramah interaktif adalah 91,67; nilai keterlaksanaan guru meminta siswa menyampaikan hasil 
eksplorasi terhadap peristiwa Fisika melalui video dan animasi yang terdapat dalam multimedia interaktif, adalah 83,33; nilai keterlaksanaan guru mengorganisasikan siswa untuk bekerja dalam kelompok mengerjakan tugas yang terdapat dalam multimedia interaktif adalah 75,00; nilai keterlaksanaan guru membimbing siswa bekerja dalam kelompok untuk mendiskusikan tugas yang terdapat dalam multimedia interaktif adalah 75,00, dan nilai keterlaksanaan guru memilih kelompok secara acak untuk mempersentasikan hasil diskusi kelompoknya adalah 75,00; nilai keterlaksanaan guru memberi umpan balik terhadap proses dan hasil kerja kelompok siswa dengan cara memberikan koreksi dan penguatan adalah 91,67.

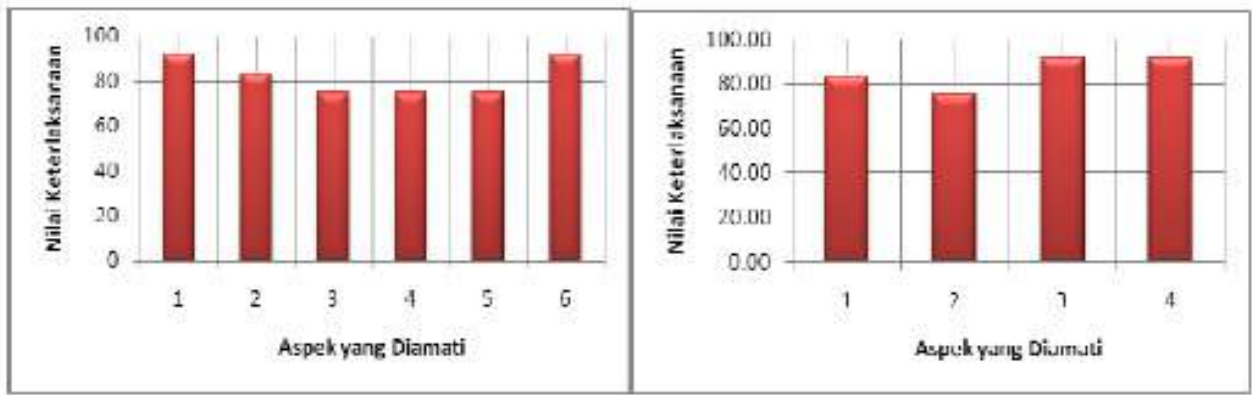

(a)

(b)

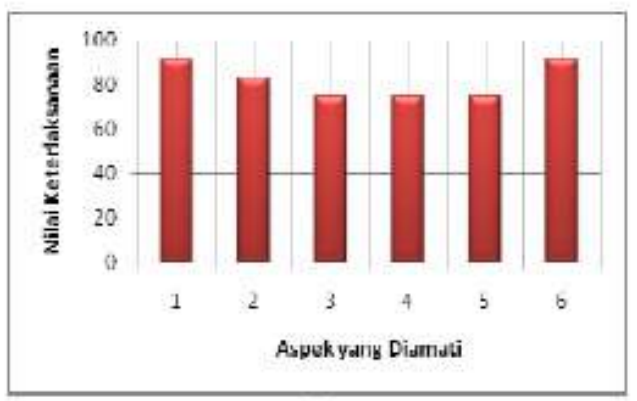

(c)

Gambar 5 (a) Nilai Rata-Rata Keterlaksanaan Multimedia Interaktif pada Kegiatan Pendahuluan, (b) Nilai Rata-Rata Keterlaksanaan Multimedia Interaktif pada Kegiatan Inti, (c) Nilai Rata-Rata Keterlaksanaan Multimedia Interaktif pada Kegiatan Penutup

Gambar 5c menjelaskan nilai keterlaksanaan aspek yang diamati selama kegiatan penutup. Nilai keterlaksanaan guru membimbing siswa untuk menyimpulkan materi pembelajaran adalah 66,67; nilai keterlaksanaan guru menyampaikan tugas baca untuk materi selanjutnya adalah 91,67; dan nilai keterlaksanaan guru memberikan pekerjaan rumah yang terdapat pada multimedia interaktif adalah 75,00.

Berdasarkan nilai keterlaksanaan multimedia interaktif pada setiap pertemuan dapat ditentukan nilai rata-rata keterlaksanaan yang menentukan kepraktisan penggunaan multimedia interaktif dalam pembelajaran Fisika. Rata-rata nilai keterlaksanaan semua aspek berada pada rentangan 66,67 sampai 91,67. Skor terendah terdapat pada aspek guru membimbing siswa bekerja dalam kelompok untuk membahas latihan atau kuis interaktif yang terdapat dalam multimedia interaktif, sedangkan skor tertinggi terdapat pada enam pernyataan. Dari data tersebut didapat nilai keterlaksanaan multimedia interaktif sebesar 82,05. Dengan demikian dapat ditarik kesimpulan bahwa multimedia interaktif praktis digunakan dalam pembelajaran Fisika. 


\section{Hasil Uji Keefektifan Multimedia Interaktif}

Untuk melihat keefektifan dari penggunaan buku ajar fisika dilakukan uji coba terbatas pada siswa kelas $\mathrm{X}_{2}$ R-SMA BI 3 Padang Dari penelitian yang telah dilakukan didapatkan data nilai tes awal dan tes akhir siswa. Dari hasil yang didapat kemudian dilakukan analisis validitas dan keandalan tes. Tes yang digunakan adalah memiliki tingkat validitas cukup tinggi dan keandalan yang tinggi.

Untuk mendapatkan nilai $t_{\text {hitung }}$ diperlukan data berupa hasil belajar siswa sebelum menggunakan multimedia interaktif dan sesudah menggunakan multimedia interaktif. Penggunaan multimedia interaktif ini dianggap efektif apabila $t_{\text {hitung }}$ lebih besar dari $t_{\text {tabel. }}$ Dari data jumlah siswa, nilai rata-rata, varian, standar deviasi, dan koefisien korelasi untuk tes awal dan tes akhir hasil uji perbadingan berkorelasi dengan nilai $t=7,46$. Untuk uji satu pihak dengan $\mathrm{n}=25$ dan derajat kebebasan $(\mathrm{dk})=23$ didapatkan nilai $\mathrm{t}$ tabel pada distribusi $\mathrm{t}$ untuk taraf nyata 0,05 didapat nilai 1,71 .

Dari hasil perhitungan didapatkan $t_{\text {hitung }}>t_{\text {tabel }}$ sehingga dapat dikemukakan bahwa terdapat perbedaan yang berarti antara hasil belajar siswa sebelum dan sesudah penggunaan multimedia interaktif dalam pembelajaran menurut KTSP di kelas X SMAN 3 Padang. Hal ini menunjukkan bahwa penggunaan multimedia interaktif adalah efektif dalam pembelajaran menurut KTSP pada siswa kelas X SMAN 3 Padang.

\section{KESIMPULAN}

Berdasarkan analisis data yang telah dilakukan dapat dikemukakan empat hasil dari penelitian ini.

1. Desain produk multimedia interaktif kinematika dan dinamika pertikel memiliki validitas yang tinggi dengan nilai rata tenaga ahli 88,14 .

2. Sebuah multimedia interaktif kinematika dan dinamika pertikel telah dihasilkan dalam bentuk DVD pembelajaran, memiliki struktur dan deskripsi yang baik sesuai dengan kharakteristik sebuah multimedia interaktif untuk pembelajaran yang ideal.

3. Multimedia interaktif kinematika dan dinamika pertikel adalah praktis dan efektif digunakan dalam pembelajaran Fisika di kelas $\mathrm{X}_{2}$ R-SMA-BI di SMAN 3 Padang. Masingmasing ditandai dengan nilai rata-rata uji kepraktisan menurut guru Fisika sebagai praktisi 87,28 dan uji kepraktisan di dalam pembelajaran 82,05 serta adanya perbedaan yang berarti hasil belajar siswa sesudah dengan sebelum menggunakan multimedia interaktif.

\section{UCAPAN TERIMA KASIH}

Penelitian ini merupakan penelitian kerjasama dengan mahasiswa pendidikan Fisika yang merupakan bagian dari penelitian hibah bersaing tahun 2010 dengan judul Pengembangan Multimedia Interaktif Kinematika dan Dinamika Partikel Untuk Pembelajaran Fisika Siswa RSMA-BI Kelas X SMAN 3 Padang. Terima kasih kepada Direktorat Jenderal Pendidikan yang telah mendanai penelitian hibah bersaing.

\section{DAFTAR PUSTAKA}

Bambang Sudibyo. (2007). Materi Sosialisasi dan pelatihan Kurikulum Tingkat Satuan Pendidikan (KTSP) SMA. Jakarta: Depdiknas.

Bambang Sudibyo. (2007). Peraturan Menteri Pendidikan Nasional No 41 Tentang Standar Proses Untuk Satuan Pendidikan Dasar Dan Menengah. Jakarta: Depdiknas. 
Prosiding Seminar Nasional Fisika

Universitas Andalas (SNFUA)

Padang, 15 Oktober 2011

ISBN 978-979-25-1953-2

Chang, Mei-Mei \& Lehman, James D. (2002). Learning Foreign Language through an Interactive Multimedia Program:An Experimental Study on the Effects of the Relevance Component of the ARCS Model. CALICO Journal, 20 (1), p-p 81-98. Hal 2.

Dadang Supriatna. (2009). Pengenalan Media Pembelajaran. Jakarta: Pusat Pengembangan Dan Pemberdayaan Pendidik Dan Tenaga Kependidikan Taman Kanak Kanak Dan Pendidikan Luar Biasa.

Didik Wirasamodra. (2008). Multimedia Pembelajaran Interaktif. http:// didikwirasamodra.wordpress.com.

E. Mulyasa. (2006). Kurikulum Tingkat Satuan Pendidikan. Bandung: Remaja Rosda Karya.

E. Mulyasa. (2007). KurikulumTingkat Satuan Pendidikan. Bandung: Remaja Rosda Karya.

Gatot Pramono. (2008). Pemanfaatan Multimedia Pembelajaran. Jakarta: Pustekkom, Diknas http://tutorial.smkn6dki.or.id/.

Haqqul Yakin.(2009). Apa itu multimedia interaktif ? http: // qinqua. files. wordpress. com/ 2009/ 02/chapter-1.pdf.

Ivandri, (2011). Manfaat Multimedia Dalam Proses Pembelajaran. http://id.shvoong.com/social-sciences/education/2145961-manfaat-multimedia-dalamproses-pembelajaran/

Kusnanunair. (2009). "Efektivitas Kinerja”. dspace.widyatama.ac.id/bitstream/ handle/.

Marhendhra Lucyana. (2006). Multimedia Interaktif sebagai Media Pemelajaran Mata Pelajaran Praktik Mesin Listrik Sub Pokok Bahasan Pelilitan Ulang Motor Induksi 1 Fasa di SMK N 4 Semarang. Fakultas Teknik:Universitas Negeri Semarang.

Mellia Liyanthy. Konsep dan Penerapan Multimedia Interaktif. Bandung:Teknik Informatika, Universitas Pasundan.

Muhammad Ardi dan Nella Azhar. (2008). Pengembangan Paket Multimedia Interaktif Sebagai Sarana Belajar Mandiri Mahasiswa. Padang: FT.

Muhammmad Ihsan. (2009). Multimedia Interaktif. http://isaninside.net/.

Nana Sudjana. (2001). Penilaian Hasil Belajar Mengajar. Bandung: PT. Remaja Rosdakarya

Puskur. (2008). Model Pengembangan Kompetensi Bagi Sekolah Bertaraf Internasional. http://www.ihsmakassar.com/.

Pustekkom. (2008). Multimedia Interaktif Belajar Menjadi Mudah dan Menyenangkan. http://www.e-dukasi.net/.

Sugiyono. (2008). Metode Penelitian Pendidikan Pendekatan Kuantitatif, Kualitatif, dan R\&D. Bandung: Alfabeta.

Suharsimi Arikunto. (2006). Prosedur Penelitian Suatu Pendekatan Praktik. Jakarta: Rineka Cipta.

Suharsimi Arikunto. (2008). Dasar-Dasar Evaluasi Pendidikan (edisi revisi) Jakarta: Penerbit Bumi Aksara.

Sumarna Surapranata. (2004). Analisis, Validitas, Reliabilitas dan Interpretasi Hasil Tes. Bandung: PT. Remaja Rosdakarya.

Sungkowo. (2009). Panduan Penyelenggaraan Program Rintisan SMA Bertaraf Internasional (R-SMA-BI). Jakarta : Depdiknas.

Tim Guru ICT SMA. (2009). Memahami Etimologi Multimedia. www.smkn1gorontalo.sch.id

Tim Mata Kuliah Multimedia Universitas Binus. (2007). Matakuliah : Sistem Multimedia. http://www.scribd.com/doc/21806968/1-Prinsip-Prinsip-Dasar-Multimedia-Interaktif 